Original Paper http://ajol.info/index.php/ijbcs $\quad$ http://indexmedicus.afro.who.int

\title{
Elaboration of a biotic index of pollution using macroinvertebrates for the monitoring of Lake Nokoué in Benin
}

\author{
Pierre GNOHOSSOU ${ }^{1 *}$, Philippe LALÈYÈ ${ }^{1}$, Pierre ATACHI ${ }^{1}$, Magali GERINO ${ }^{2}$, \\ Sebastien BROSSE ${ }^{3}$ and Jacques MOREAU ${ }^{4}$
}

\author{
${ }^{1}$ Laboratoire d'Hydrobiologie et d'Aquaculture / Faculté des Sciences Agronomiques / Université d'Abomey \\ Calavi 01 BP 526 Cotonou, Bénin. \\ ${ }^{2}$ UMR5177 LEH CNRS - UPS Laboratoire d'Ecologie des Hydrosystèmes, 29 rue Jeanne Marvig. 31055 \\ Toulouse, France. \\ ${ }^{3}$ Laboratoire Dynamique de la Biodiversité (LADYBIO) CNRS/UPS Université Paul Sabatier, Bâtiment 4R3 \\ 31062 Toulouse cedex 4 , France. \\ ${ }^{4}$ Laboratoire d'Agronomie Environnement et Ecotoxicologie, I.N.P./E.N.S.A.T. B.P. 107, Auzeville Tolosane, \\ 31326 Castanet Tolosan, France. \\ *Corresponding author; E-mail: gnonhossou@yahoo.com; Tel: 0022995157063; Fax: 0229303084
}

\section{ACKNOWLEDGMENTS}

This work was financed by the International Foundation for Science (IFS).

\begin{abstract}
A study on the relationships between the physicochemical parameters and of the macroinvertebrates of the Lake Nokoué was carried out for the purpose of developing a biotic index of pollution. A total of 96 stations were prospected twice during the flooding and the dry seasons from September 2004 to February 2006. At each station, seven physicochemical parameters were measured and macroinvertebrates were collected. Canonical analyses of correspondence were used to show the relations between the parameters of the environment and the macroinvertebrates. A self-organizing map (SOM) of Kohonen allows the categorization of the studied stations into four groups according to different degrees of pollution. Rough scores were allotted to each taxon according to its abundance in the various groups of stations determined by the SOM for each campaign. A synthesis of the data obtained from the four field surveys allows the assignment of a score to each taxon according to its abundance in the different groups of stations. A biotic index was developed and used for the evaluation of the level of pollution of the stations studied. It then emerged that the borders of the lake present a «poor quality» of water; however, during the dry season there is slight improvement.
\end{abstract}

(C) 2015 International Formulae Group. All rights reserved.

Keywords: Biotic index, pollution, invertebrates, lagoons, Benin, West Africa.

\section{INTRODUCTION}

The permanent control of water quality is crucial for the preservation of the aquatic ecosystems. Methods of monitoring the health of aquatic ecosystems based only on the use of physical and chemical measures such as the concentration of pollutants from rivers cannot assess the capacity of the 
ecosystems to maintain a functional balance (Stod-Dard et al., 2006). The biological indicators have greater power of integrating information, but cannot completely replace the physical and chemical indicators (Rioux and Gagnon, 2001). Indeed, the biological and ecological communities living in an ecosystem are a reflection of the characteristics (chemical, physical and biological) of the environment, both past and present. Moreover, these include both the effect of current events as well as those that are unexpected (Ohio EPA, 1987).

Among all living indicators of pollution, invertebrates hold an important place and are at the basis of many biotic indices. The majority of macroinvertebrates have limited possibilities for moving. The recolonization of polluted sectors is possible from the adults of the following generations, those adults being drawn from non-polluted sectors (Tachet et al., 2000). Beck (1955) was the first to mention a biotic index by classifying macroinvertebrates according to their organic pollution tolerance. But this index did not take into account the diversity of organisms. Moreover, many other biotic indexes have been developed in different countries: for instance, the Trent Biotique index (TBI) in England (Woodiwiss, 1964) and the Normalized Global Biological Index (IBGN) (AFNOR, 1992) in France.

Other biological indicators such as fish and bacteria are used by some authors (Aguilar Ibarra, 2004).

Nowadays, most of the indices elaborated and utilized for the evaluation of water quality have been elaborated in Europe (IBGN, BMWP, BBI), in the United States (FBI, BI), in Australia and New Zealand (SIGNAL, MCI) (AFNOR, 1992; Resh and Jackson, 1993; Stark, 1993; Mary, 1999) and in Colombia (Mathuriau, 2002). The validity of these indices goes slightly beyond the limits of the national or regional geographical context in which they have been defined.
The objective of this study is, firstly, to characterize the existing relationships between communities of macroinvertebrates and the measured physicochemical parameters of the water and, secondly (rewrite the objective with regard of the work done), to elaborate a new index of bioperturbation in order to characterize the level of pollution of Lake Nokoué.

\section{Study area}

Located in West Africa, Benin is divided into two major climatic zones: in the north, the climate is tropical with the rainy season extending from April to October with a peak in August and September. In the South, the climate is subequatorial with two rainy seasons of unequal importance. The longer rainy season lasts from mid-March to midJuly and the shorter rainy season from early September to late October. The Dry season is similar. Average annual rainfall is $1150 \mathrm{~mm}$ in Cotonou (Adounvo et al., 2007).

Located in the Southeast of Benin $\left(6^{\circ} 25^{\prime} \mathrm{N}, 2^{\circ} 36 \mathrm{E}\right)$, Lake Nokoué (Figure 1) is the most important brackish water (about 150 $\mathrm{km}^{2}$ in low water period) in Bénin (Lalèyè et al., 2003). It has an average length of $20 \mathrm{~km}$ in its East-West side and $11 \mathrm{~km}$ width in its North-South side. Lake Nokoué is directly linked to the Atlantic Ocean through the Cotonou channel which is $4.5 \mathrm{~km}$ length. The depths measured in 2002 varied between 0.4 and $3.4 \mathrm{~m}$ with an average of $1.20 \mathrm{~m}$ (Adounvo et al., 2007). Water salinity varies from less than $1 \%$ o during the flooding season to $31 \%$ o during the dry season (Adounvo et al., 2007). The oxygen content varies greatly inside the lake; from de $0.5 \mathrm{mg} / \mathrm{l}$ in the areas of great pollution (example of Ganvié station) to $9.0 \mathrm{mg} / \mathrm{l}$ in the areas close to the sea (Niyonkuru et al., 2007). According to the same author, the temperature of water in surface varies between 25.3 to $33.1{ }^{\circ} \mathrm{C}$, the transparence goes from 0.2 to $0.8 \mathrm{~m}$, the maximum being obtained during the dry 
season .The $\mathrm{pH}$ varies between 6.5 and 8.2. Pollution in the lake is essentially organic. The use of pesticide and chemical nutrients in agriculture is not well developed and there is little industry in Benin (Gnohossou 2006).

The hydrological regime of Lake Nokoué is characterized by:

- A period of low water from December to April;

- A slight rising of water from May to August which corresponds to the longer rainy season in the south;

- A heavy rising of water from September to November which corresponds to the longer rainy season in the North.

\section{MATERIALS AND METHODS Sampling stations}

The lake has been divided into seven zones according to the salinity levels (distance from the ocean) and the nature of the sediment. In each zone, three habitats have been considered including a natural subtract (macrophytes of the banks), an artificial subtract (Acadja, fish parks) and the lake without macrophytes and Acadja. For each habitat, five stations have been chosen with consideration of a pollution gradient going from the less polluted station (station of reference) to the most polluted station, the criteria of characterization of pollution being the concentration of oxygen in water between 06:00 and 09:00.

It must be noted that at the centre of the lake, an area with no littoral vegetation and low-polluted, only 6 stations were visited. A total of 96 stations have been prospected twice during flooding and low water seasons from September 2004 to February 2006.

\section{Field and laboratory works}

Physicochemical

parameters

(temperature, depth, salinity, transparency, conductivity, $\mathrm{pH}$, oxygen) have been measured in situ with portable or in-field instruments of measurement (HI9143
Oxymeter portable, Pionneer 10 pHmeter, Pionneer 30 Conductimeter, Thermometer and Secchi Disk). This protocol has been followed in September 2004 (flooding season), in February 2005 (low water season), in September 2005, and in February 2006. During those four sampling periods on the field, samples of water have been taken and preserved at $4{ }^{\circ} \mathrm{C}$ for the analyses of ammonium ions (NH4+), which have been carried out through the method of test cards the same day in the laboratory. The organic matter content of sediments was calculated by the loss of ignition method: drying at $105{ }^{\circ} \mathrm{C}$, $24 \mathrm{~h}$ then combusting at $520{ }^{\circ} \mathrm{C}, \quad 6 \mathrm{~h}$ (Kristensen and Anderson, 1993).

At each station, a sample of macrophyte was taken by handle for the macroinvertebrate living in it. The sediment (in Acadja and the lake itself) was collected using a sort of "modified surber" of $50 \mathrm{~cm}$ of width and $30 \mathrm{~cm}$ of height with a mesh net of $300 \mu \mathrm{m}$. It was dragged along the bottom like a drag over a distance of 3 metres with a rope. Each sample of macroinvertebrates has been preserved in formaldehyde at $10 \%$.

In the laboratory, a complete sorting of collected samples was done in which macroinvertebrates were extracted. They were then transferred into a solution of $70 \%$ alcohol and identified under dissecting microscope or naked eye, and counted using an "Olympus SZ40"dissecting microscope. Macroinvertebrates were identified using some keys (Hayward, 1980; Durand and Lévêque, 1981; McCafferty, 1981; FAO, 1992; Tachet et al., 2000).

\section{Statistical analysis}

Statistical analyses were realised using the SOM toolbox (MATHWORKS Inc, 1999). In all cases, the dependent variable has been the percentage in number of given individual taxa in a given sample. The absolute abundance utilised is the number of individuals harvested by sampling operation 
with the Surber net or by samples on macrophytes.

\section{Networks of artificial neurons and hierarchical classification}

The collected data were studied using networks of artificial neurons (Lek et al., 1996, 2000). There are many types of artificial neurons; but, for ecological analysis, the most frequent used are of two types: supervised and non-supervised networks. An example of network of artificial neurons is the network of « retropropagation » ("back-propagation network" - BPN), whereas a non-supervised network is used in the outworking of the method of Kohonen's self-organising map (SOM). In our case, we used the latter.

The hierarchical classification was realised using «U-matrix »'s algorithms following the analysis with the neurons' network. The results thus obtained have been submitted to characterization analysis according to Ward's method (Ward, 1963) coupled with Chebychev's Euclidian distance (Diday, 1974; Michalski et al., 1981).

\section{The Self-organizing Map (SOM) of Kohonen}

Initially, the Self-Organising Map (SOM), first developed by Kohonen (1982), was used for the pattern recognition aspect of the project. SOM is an unsupervised neural network that identifies patterns in data, clusters them into a predefined number of classes, and orders the classes in twodimensional output spaces such that near neighbours in data space are near neighbours in output space. Clustering and ordering are integrated into one process using a similarity metric based on Euclidean distances and a neighbourhood function which ensures that near neighbours in the output space represent similar patterns.

For the whole Lake Nokoué, we established a Kohonen self-organizing map (SOM Kohonen, 2001). The aim was to classify the quality of a station from the composition of its living community and the environmental characteristics of the site.
Indeed, this method has a notable advantage of visually representing non-linear relationships (Lek et al., 2000).

The data consisted of biological samples taken from 96 stations in the Nokoué Lake prospected twice during the flooding and the dry seasons from September 2004 to February 2006. The sampling procedure covered 39 benthic macroinvertebrate families, and recorded their relative abundance in each sample. In addition, the data included 7 environmental characteristics of the sampling stations. All of which were expressed as continuous variables. These were transformed to discrete variables when input to the system.

\section{Canonic Analysis of Correspondence}

Canonic analysis of correspondence has been realised using data obtained from each field survey in order to show relationships between the physicochemical parameters and invertebrates relative abundance according to Manly (1995).

\section{Determination of biotic index of pollution}

The biotic index of pollution we suggest is based on the method of average scores attributed to stations, already applied by Armitage et al. (1983) in order to evaluate the quality of water in Great Britain. This method does not depend on the number of taxa but on the score attributed to them.

The index is calculated by adopting the principle of Mathuriau (Mathuriau, 2002) which considers the average of the scores of taxa observed at a given station.

IBVC (Indice biotique de Valle del Cauca $)=\sum \mathrm{Si} / \mathrm{N} \quad$ with $\mathrm{Si}=$ score of taxon, $\mathrm{i}=$ indicator and $\mathrm{N}=$ number of taxon indicators presents in the samples. These are scores that we have determined and that are proper to the taxa of Nokoué lagoon given to their sensitivity to pollution. These taxa were considered because of their presence during the rising as well as low water period.

In this study, the method of stations group (Lenat, 1988) has been used to obtain 
scores of taxa that will serve as a basis for the elaboration of the biotic index mentioned above. In order to calculate the scores, several computations have been done. The abundance per taxon has been calculated for each group of stations marked from G1 to G4. The relative frequency of taxa in each group of stations has been calculated. A rough score has been calculated for each taxon by multiplying its relative frequency within each group by $100 ; 75 ; 50$; and 25 according to the quality of the group's stations and by adding the obtained values for the four groups of stations (Table 2). For instance, during the first flood in September 2004, the raw score for Aoridae $=0.31 * 100+0.05 * 75+0.62 * 50$ $+0.02 * 25=66.25$. That means that $31 \%$ Aoridae were observed in the group of stations less polluted and $2 \%$ in the group most polluted.

A hierarchical classification based on the raw scores allowed defining 6 groups of taxa. A net score from 5 (very polluosensitive) to 1 (very polluo-resistant) has then been attributed to the taxa according to the group to which they belong (Mathuriau, 2002).

The biotic index of each station has been calculated by adding the net scores of the taxa indicators present, then divided by the number of taxon indicators, the maximum value of the index being 5 (good quality water) and the minimum 1 (very polluted water). The stations having an index values superior to 4 can then be considered of a very good quality. The stations having index values comprised respectively between 4 and $3 ; 3$ and 2, and between 2 and 1 can be considered respectively as stations where water is of good, bad, and very bad quality.

\section{Realization of map of distribution of pollution on Lake Nokoué}

A map of spatial distribution has been produced with the SURFER software from the spatial structure of biotic indices (calculated for each station) and detected by the variogram.

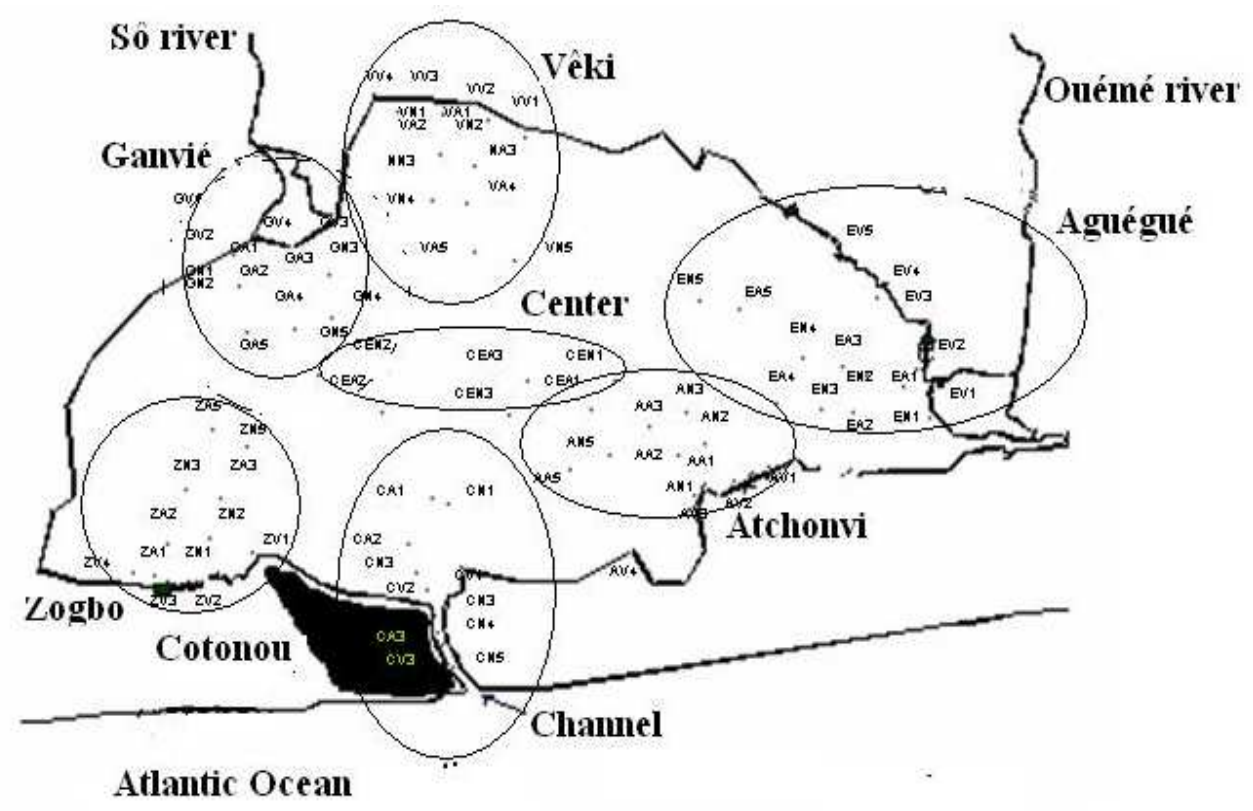

Figure 1: Map of the lake Nokoué mentioning the localization of the stations defined for the study of the spatial distribution of pollution (the codes of the stations are made of a letter indicating zone (E for Embouchure, $V$ for Vêki, $G$ for Ganvié, $\mathrm{Z}$ for Zogbo $\mathrm{C}$ for Channel $\mathrm{CE}$ for Center and $\mathrm{A}$ for Atchonvi), then of a letter indicating the type of habitat ( $\mathrm{N}$ for naked lake or interstitial water, $\mathrm{V}$ for vegetation, $\mathrm{A}$ for acadja) and, finally, the number of the station for the zone and the habitat considered. Example: GN1= the first interstitial water station of Ganvié). 


\section{RESULTS}

Relationships between physicochemical parameters and invertebrates have been carried out twice for each season (September 2004 (flooding season), February 2005 (lower water season), September 2005, and February 2006).

We present the detailed analysis concerning the first flooding from September 2004. The other detailed data are available on request to the first author, but have been taken into account in the elaboration of the present index. In effect, four campaigns have been done for the elaboration of the index and here we present the detailed analysis of one campaign and we use the synthesis of the tree others to elaborate our index.

\section{Specific richness}

39 taxa have been identified in the lake during the four field survey, covering all the habitats (Vegetation, acadjas and sediments): 12 insects, 15 crustaceans, 9 molluscs, 3 annelids (Table 1). 9 taxas (Planorbidae, Parguridae, Lymnaeidae, Geryonidae, Batidae, Pleidae, Caenidae, Ceratopogonidae, Tipulidae) have been observed only during the flooding period (in all habitat) and 1 (dryopidae) only during low water period (in macrophyte). 29 species have been observed all the time in the lake (in all habitat).

\section{Results of statistical analyses: example of the flooding period (September 2004)}

The results obtained with the neuronal networks show four groups of stations according to the importance of the pollution (Figure 2): the highly polluted stations, the lowly polluted stations, and two groups of intermediate stations. Each group was mainly associated with the characteristics of the water types. For instance, group 1 is mainly consisted of site of upper transparency, oxygen, low level of ammonium and organic matter. The station of group 2 are characterized by high level of oxygen and transparency but less than group 1 and low level of ammonium and organic matter (Table 2) but higher than group 1, group 3 characterized by intermediate values of these parameters . Finally, group 4 is characterized by low value of oxygen and high value of organic matter.

Canonic shows four groups of invertebrates (Figure 3) according to their sensitivity to the pollution: very sensitive, sensitive, less sensitive, and resistant to pollution. At the left of the diagram we have two groups correlated with the level of organic matter and ammonium and at the right we have also two groups characterized by high level of oxygen and transparency.

Table 2 presents the relative abundances of the different taxa in each group, their raw scores calculated as quoted above as well as the values of the different physicochemical parameters at the level of the groups of the stations.

\section{Determination of biotic index of pollution Attribution of Scores}

Table 3 presents rough scores of each taxon during the four field surveys. The Analysis of Variance (Table 4) shows that there is no significant difference $(p>0.05)$ between the four field surveys and allows then to calculate an average score for each taxon.

The hierarchical analysis of the rough scores of the different taxa during the four field surveys allows the classification of the latter in five groups (Figure 4). A score between 5 (very polluo-sensitive) to 1 (very polluo-resistant) has been attributed to the taxa (Table 5) according to the group to which they belong.

An examination of Table 5 shows that the insects represent the group of invertebrates as the most resistant to pollution with shrimps, crabs, and molluscs being the most sensitive organisms. The small shellfishes present variable sensitivity to pollution. Thus, the Aoridae, very abundant, can be considered as resistant, whereas, on the opposite side, the Mysidae are very vulnerable. 
Evaluation of the quality of water of the studied stations with the proposed biotic indexes and comparison with other indices

The values of the index vary between 4.75 for the station $\mathrm{CN} 2$ to 1 for the station GN3.

In general, during flooding periods, the stations located on the border of the lake is "polluted" particularly near Ganvié, a lakeshore village built on piles, where water at several stations is of "very polluted" whereas down to the centre and to the channel stations, the water becomes cleaner and cleaner (Figure 5). However, during the dry season, the water in the centre and the border stations presents a good quality (Table 6). Ganvié remains the most polluted area but there is a clear improvement during the low water period.

Table 6 shows that the biotic index values within the stations of the centre of the lake and of the stations numbered 5 (i.e., the less polluted of the "column of water" and "acadja" habitats) have little variations according to the season. On the contrary, the stations closer to the bank generally have weak values during the flooding season and are heightened during the low water period. However, very few polluted stations such as GV3 remain polluted during the whole year.

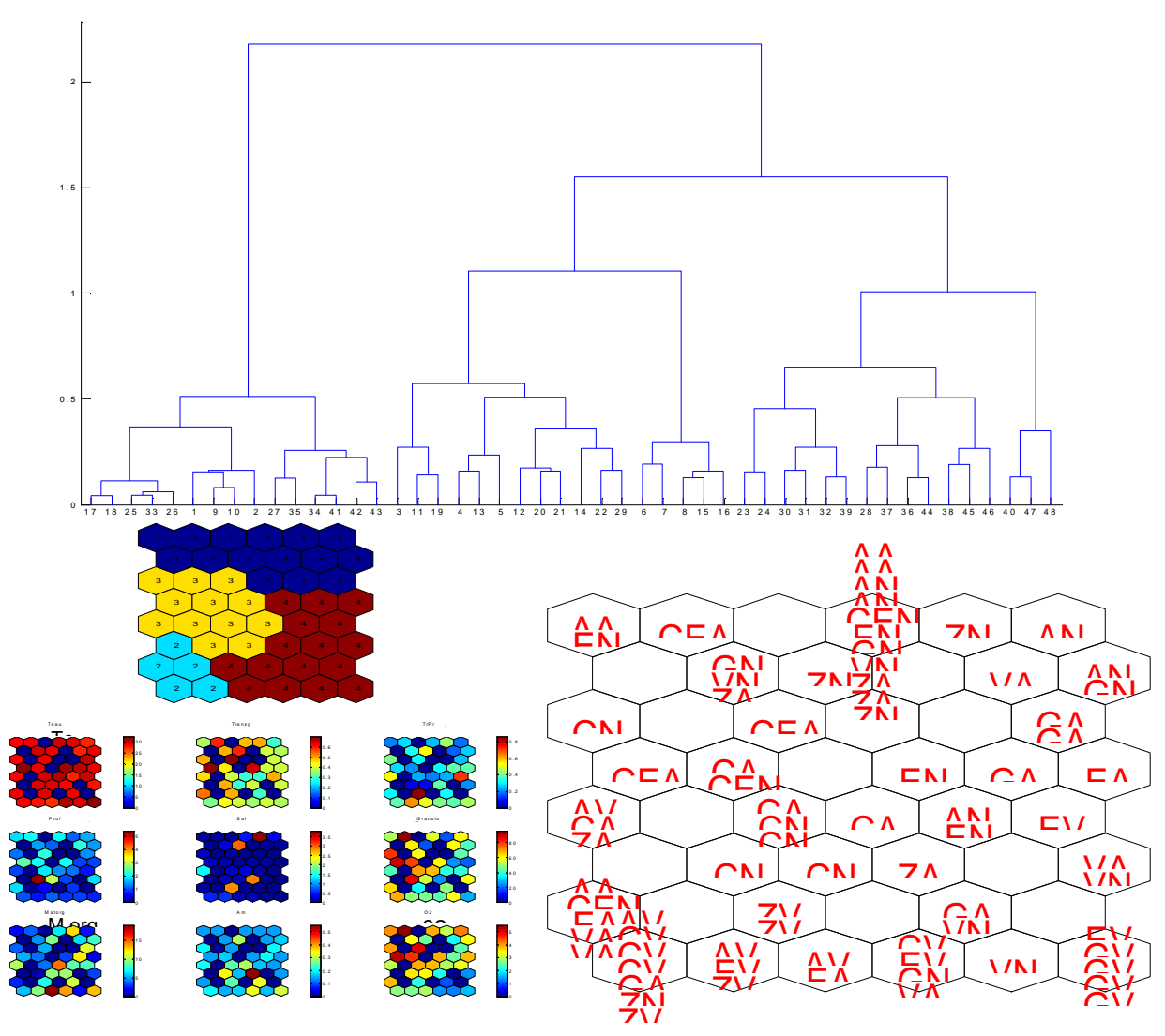

Figure 2: Results of SOM analysis carried out on the data of the first flooding season showing the groups of stations according to their degree of pollution. 


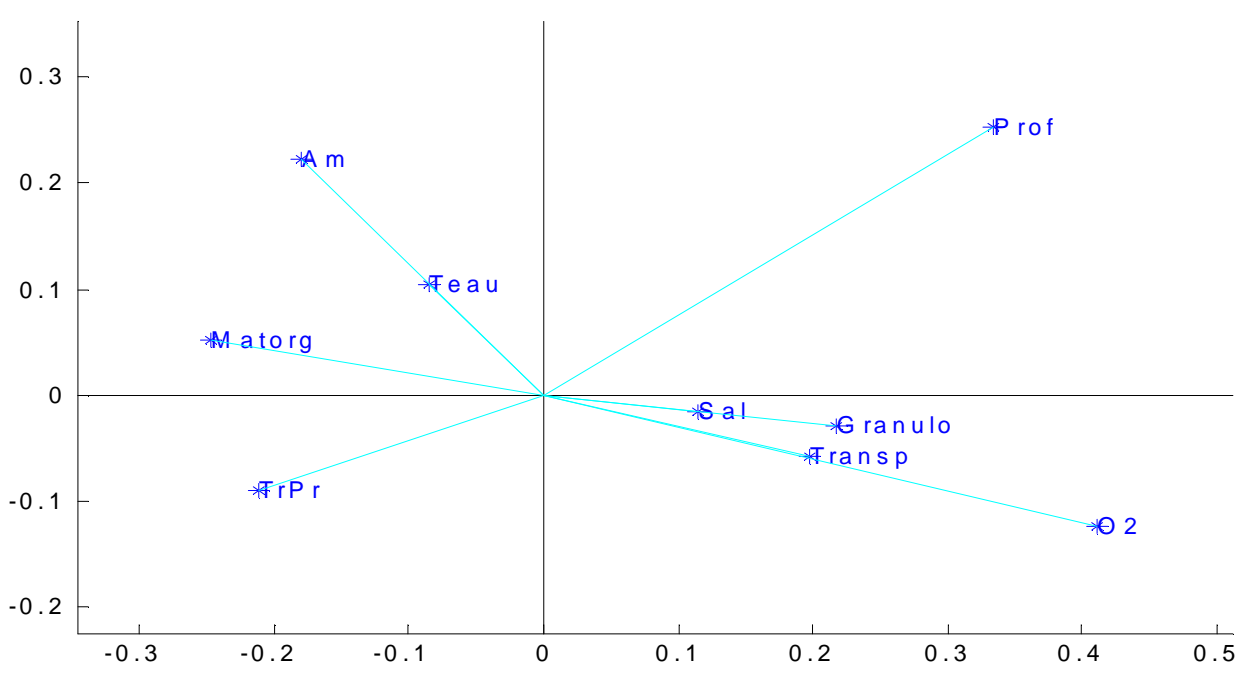

Figure 2: Results of SOM analysis carried out on the data of the first flooding season showing the groups of stations according to their degree of pollution.

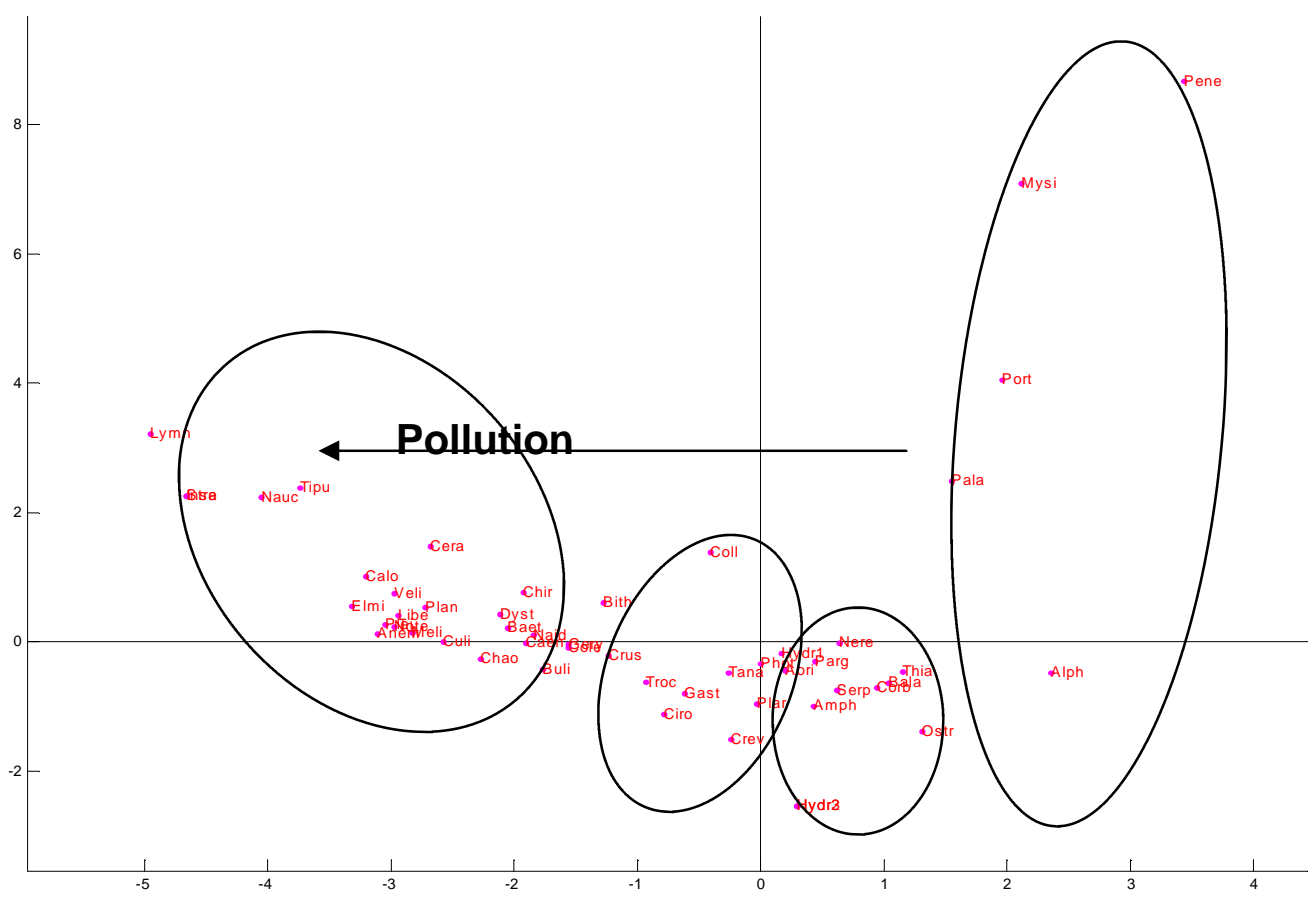

Figure 3: Results of CCA analysis carried out on the data of the first flooding season showing the groups of macroinvertebrates according to their tolerance to pollution. 
Rescaled I istare Cluster Combire

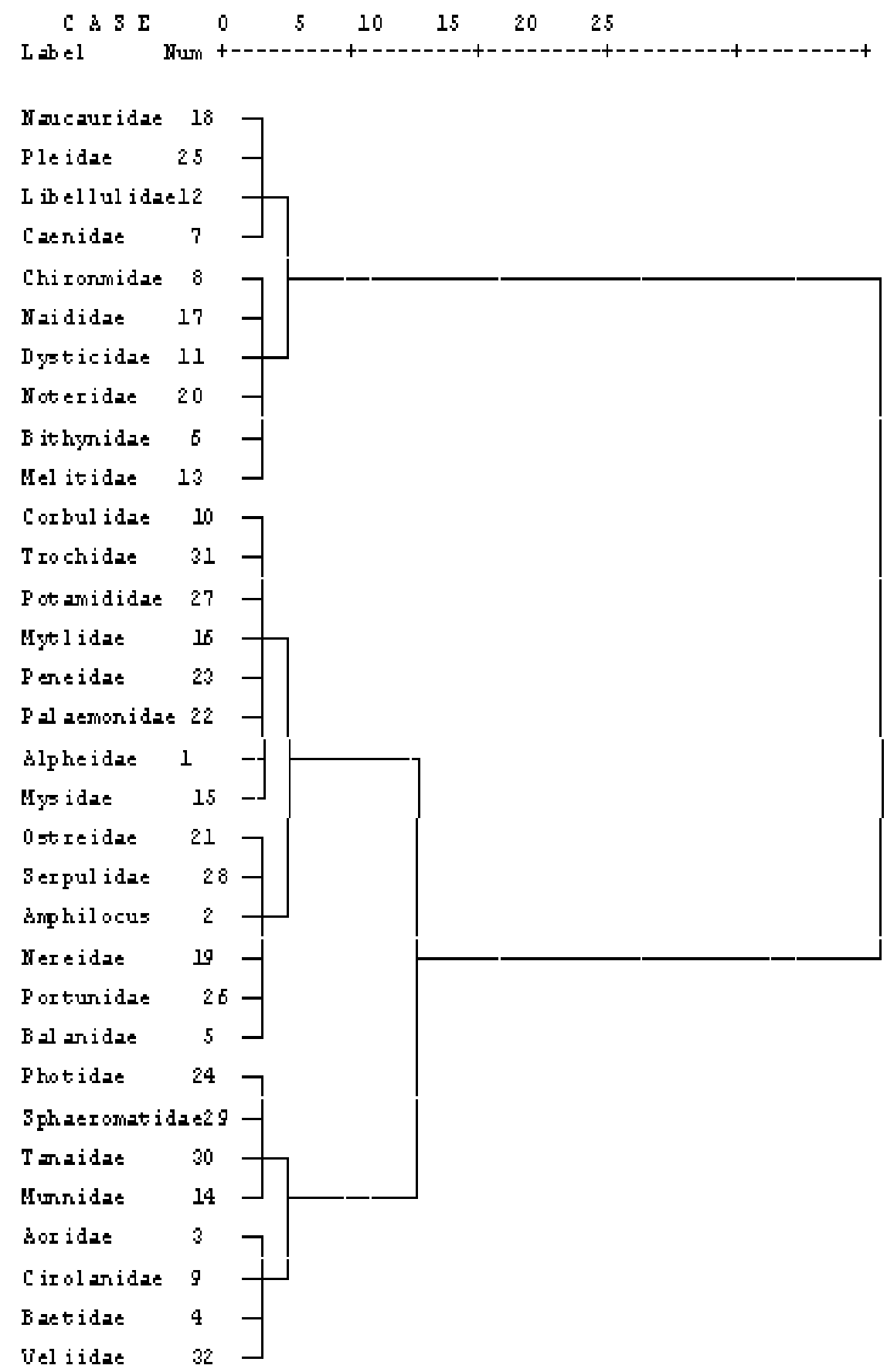

Figure 4: Dendrogramm showing taxa with rough similar scores as presented on Table 2. 


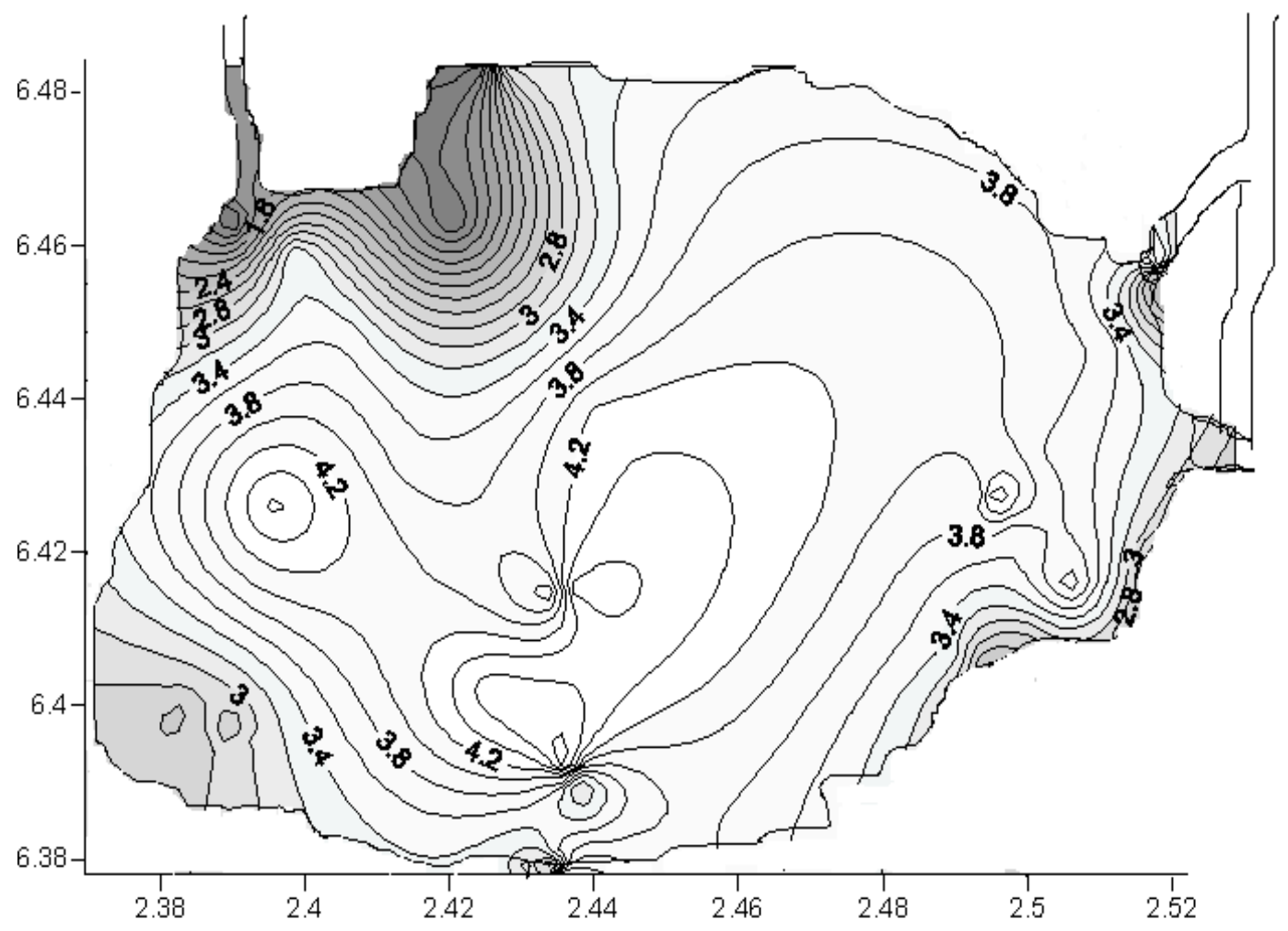

Figure 5: Spatial repartition of the biotic index on the lake Nokoué in September 2004.

Table 1: List of invertebrates taken into account for the pollution study.

\begin{tabular}{|c|c|c|c|c|}
\hline & Taxa & & & Codes \\
\hline $\begin{array}{l}\text { Great } \\
\text { groups }\end{array}$ & Family & Genus & Species & \\
\hline \multirow[t]{11}{*}{$\begin{array}{l}\text { Small } \\
\text { crustaceans }\end{array}$} & Aoridae & Grandidierella & $\begin{array}{l}\text { Grandidierella } \\
\text { bonnieroides }\end{array}$ & Aor \\
\hline & Melitidae & Quadrivisio & Quadrivisio beninensis & Mel \\
\hline & Amphilocus & Amphilocus & Amphilocus brunneus & Amp \\
\hline & Photidae & Photis & Photis sp & Pho \\
\hline & Sphaeromatidae & Cassidinidea & Cassidinidea $\mathrm{sp}$ & Sph \\
\hline & Cirolanidae & Cirolana & Cirolana chaloti & Cir \\
\hline & Tanaidae & Sinelobus & Sinelobus stanfordi & Tan \\
\hline & Balanidae & Balanus & Balanus sp & Bal \\
\hline & Mysidae & Ropalophtalmus & $\begin{array}{l}\text { Ropalophtalmus } \\
\text { africana }\end{array}$ & Mys \\
\hline & Paguridae & Pagurus & Pagurus sp. & Par \\
\hline & Munnidae & Uromunna & Uromunna powelli & Mun \\
\hline
\end{tabular}




\begin{tabular}{|c|c|c|c|c|}
\hline \multirow[t]{3}{*}{ Shrimps } & Palaemonidae & Macrobrachium & Macrobrachium $s p$. & $\mathrm{Pal}$ \\
\hline & Penaeidae & Penaeus & Penaeus sp & Pen \\
\hline & Alpheidae & Alpheus & Alpheus sp & Alp \\
\hline Crabs & Portunidae & Callinectes & Callinectes sp. & Por \\
\hline \multirow[t]{4}{*}{ Mollusk } & Potamididae & Tympanotonus & $\begin{array}{l}\text { Tympanotonus } \\
\text { fuscatus }\end{array}$ & Pot \\
\hline & Hydrobiidae & Hydrobia & Hydrobia sp & Hyd \\
\hline & Mytilidae & Mytilus & Mytilus sp & Myt \\
\hline & Trochidae & Neritina & Neritina sp. & Tro \\
\hline \multirow[t]{2}{*}{ Bivalvs } & Corbulidae & Corbula & Corbula sp. & Cor \\
\hline & Ostreidae & Crassostrea & Crassostrea gasar & Ost \\
\hline \multirow[t]{3}{*}{ Worms } & Nereidae & Nereis & Nereis sp. & Ner \\
\hline & Serpulidae & Serpula & Serpula sp. & Ser \\
\hline & Naididae & & & Nai \\
\hline \multirow[t]{9}{*}{ Insects } & Chironomidae & Chironomini & Chironomini sp. & Chi \\
\hline & Baetidae & Baetis & Baetis sp. & Bae \\
\hline & Pleidae & Plea & Plea sp. & $\mathrm{Ple}$ \\
\hline & Dysticidae & & & Dys \\
\hline & Veliidae & Microvelia & Microvelia sp, & Vel \\
\hline & Caenidae & Caenomedea & Caenomedea sp. & $\mathrm{Cae}$ \\
\hline & Noteridae & & & Not \\
\hline & Naucauridae & Naucauris & Naucauris sp, & $\mathrm{Nau}$ \\
\hline & Libellulidae & & & Lib \\
\hline
\end{tabular}

Table 2: Repartition (in \% of the total) of taxa considered between the 4 groups of stations noted G1 with G4 and represented on Figure 4 above on the left side, Rough scores of these taxa, during the first flooding period.

\begin{tabular}{lccccc}
\hline \multicolumn{1}{c}{ Level of pollution } & Very low & low & Polluted & Highly polluted & \\
\hline \multicolumn{1}{c}{ Coefficient } & $\mathbf{1 0 0}$ & $\mathbf{7 5}$ & $\mathbf{5 0}$ & $\mathbf{2 5}$ & \\
\hline \multicolumn{1}{c}{ Groups } & $\mathbf{G 3}$ & $\mathbf{G 1}$ & $\mathbf{G 2}$ & $\mathbf{G 4}$ & Gross scores \\
\hline Aoridae & 0,31 & 0,05 & 0,62 & 0,02 & 66,43 \\
Melitidae & 0 & 0,01 & 0,12 & 0,88 & 28,28 \\
Amphilocus & 0,26 & 0,06 & 0,65 & 0,03 & 63,76 \\
Photidae & 0,03 & 0,05 & 0,87 & 0,05 & 51,54 \\
Sphaeromatidae & 0,07 & 0,08 & 0,72 & 0,14 & 51,96 \\
Cirolanidae & 0,26 & 0,04 & 0,63 & 0,07 & 62,04 \\
Tanaidae & 0,03 & 0,05 & 0,86 & 0,06 & 51,23 \\
Balanidae & 0,04 & 0,11 & 0,85 & 0 & 54,73 \\
Mysidae & 0,8 & 0,18 & 0 & 0,02 & 93,89 \\
Parguridae & 0,33 & 0 & 0,67 & 0 & 66,67 \\
Palaemonidae & 0,75 & 0 & 0,06 & 0,19 & 82,69 \\
Peneidae & 0,93 & 0 & 0,07 & 0 & 96,43 \\
& & 2907 & & &
\end{tabular}




\begin{tabular}{lccccc} 
Alpheidae & 0,88 & 0,12 & 0 & 0 & 97,12 \\
Portunidae & 0,58 & 0,06 & 0,33 & 0,03 & 79,55 \\
Potamididae & 0,03 & 0,96 & 0,01 & 0 & 75,42 \\
Hydrophilidae & 0,03 & 0,04 & 0,09 & 0,83 & 31,94 \\
Corbulidae & 0,15 & 0,77 & 0,06 & 0,01 & 76,6 \\
Ostreidae & 0 & 0,09 & 0,91 & 0 & 52,27 \\
Trochidae & 0,5 & 0 & 0,5 & 0 & 75 \\
Nereidae & 0,34 & 0,26 & 0,29 & 0,11 & 70,81 \\
Serpulidae & 0 & 0,01 & 0,98 & 0,01 & 50,17 \\
Naididae & 0,02 & 0,06 & 0,24 & 0,67 & 35,77 \\
Chironomidae & 0,01 & 0,12 & 0,15 & 0,72 & 35,21 \\
Baetidae & 0 & 0 & 0,03 & 0,97 & 25,68 \\
Pleidae & 0 & 0 & 0 & 1 & 25 \\
Dysticidae & 0 & 0 & 0 & 1 & 25 \\
Veliidae & 0 & 0 & 0 & 1 & 25 \\
Caenidae & 0 & 0,02 & 0 & 0,98 & 26,09 \\
Noteridae & 0 & 0 & 0 & 1 & 25 \\
Naucauridae & 0 & 0 & 0 & 1 & 25 \\
Libellulidae & 0 & 0 & 0 & 1 & 25 \\
Matière organique & 8,27 & 7,08 & 7,52 & 11,28 & \\
Ammoniaque & 0,18 & 0,17 & 0,23 & 0,32 & \\
O2 & 3,31 & 3,41 & 2,15 & 1,75 & \\
Transparence & 0,46 & 0,46 & 0,37 & 0,38 & \\
\hline
\end{tabular}

Table 3: Gross Score of taxa considered during the four field surveys.

\begin{tabular}{|c|c|c|c|c|c|}
\hline \multirow[t]{2}{*}{ Taxa } & \multicolumn{4}{|c|}{ Gross scores } & \multirow[t]{2}{*}{ Means } \\
\hline & $\mathbf{1}^{\text {st }}$ flooding & $2^{\text {nd }}$ flooding & $1^{\text {st }}$ low water & $2^{\text {nd }}$ low water & \\
\hline Aoridae & 66,43 & 66,69 & 62,26 & 56,63 & 63,01 \\
\hline Melitidae & 28,28 & 37,41 & 40,46 & 27,08 & 33,3 \\
\hline Amphilocus & 63,76 & 77,24 & 61,5 & 85,92 & 72,1 \\
\hline Photidae & 51,54 & 67,51 & 32,23 & 71,56 & 55,71 \\
\hline Sphaeromatidae & 51,96 & 67,52 & 42,17 & 81,52 & 60,79 \\
\hline Cirolanidae & 62,04 & & 49,53 & 40,83 & 50,8 \\
\hline Balanidae & 54,73 & & 75,68 & 80,07 & 70,16 \\
\hline Tanaidae & 51,23 & 65,4 & 39,71 & 97,14 & 63,37 \\
\hline Mysidae & 93,89 & 89,28 & 51,04 & 86,11 & 80,08 \\
\hline Munnidae & & 32,12 & 25,37 & 73,96 & 43,82 \\
\hline Palaemonidae & 82,69 & 75 & 83,78 & 100 & 85,36 \\
\hline Peneidae & 96,43 & 87,33 & 84,96 & 89,48 & 89,55 \\
\hline Alpheidae & 97,12 & 64,63 & 75 & & 78,92 \\
\hline Portunidae & 79,55 & 59,51 & 72,41 & 89,65 & 75,28 \\
\hline Potamididae & 75,42 & 97,93 & 90,19 & 76,26 & 84,95 \\
\hline Hydrophilidae & 31,94 & 25,84 & 53,94 & 28,42 & 35,03 \\
\hline
\end{tabular}




\begin{tabular}{lccccc} 
Corbulidae & 76,6 & 79,22 & 79,23 & 74,42 & 77,36 \\
Mytlidae & & 85,89 & 71,43 & 86 & 81,1 \\
Ostreidae & 52,27 & 75 & 74,72 & 76,73 & 69,68 \\
Trochidae & 75 & 81,37 & 73,98 & 72,09 & 75,61 \\
Nereidae & 70,81 & 65,41 & 64,86 & 85,57 & 71,66 \\
Serpulidae & 50,17 & 92,19 & 66,36 & 79,57 & 72,07 \\
Naididae & 35,77 & 42,49 & 65,61 & 25,92 & 42,44 \\
Chironomidae & 35,21 & 50,83 & 66,09 & 25 & 44,28 \\
Noteridae & 25 & 25 & 50 & 25 & 31,25 \\
Naucauridae & 25 & 25 & & 25 & 25 \\
Libellulidae & 25 & & & 25 & 25 \\
Veliidae & 25 & 75 & 47,21 & & 49,07 \\
Caenidae & 26,09 & 25 & & & 25,54 \\
Dysticidae & 25 & 25 & 50 & 25 & 31,25 \\
Baetidae & 25,68 & 62,06 & & & 43,87 \\
Pleidae & 25 & 25 & & & 25 \\
\hline
\end{tabular}

Table 4: ANOVA for gross scores for the four field surveys.

\begin{tabular}{lccccc}
\hline & $\begin{array}{c}\text { Sum of } \\
\text { squares }\end{array}$ & ddl & $\begin{array}{c}\text { Means of } \\
\text { squares }\end{array}$ & F & Signification \\
\hline $\begin{array}{l}\text { Inter- } \\
\text { groups }\end{array}$ & 1830,967 & 3 & 610,322 & 1,123 & 0,343 \\
$\begin{array}{l}\text { Intra- } \\
\text { groups }\end{array}$ & 61403,082 & 113 & 543,390 & & \\
Total & 63234,050 & 116 & & & \\
\hline
\end{tabular}

Table 5: Attribution of the scores to different taxa classified by decreasing scores.

\begin{tabular}{lcl}
\hline Taxa & Scores adopted & Great groups \\
\hline Peneidae & 5 & Shrimps \\
Palaemonidae & 5 & Shrimps \\
Alpheidae & 5 & Shrimps \\
Mysidae & 5 & Small crustacean \\
Potamididae & 5 & Mollusks \\
Mytlidae & 5 & Mollusks \\
Corbulidae & 5 & Mollusks \\
Trochidae & 5 & Mollusks \\
Portunidae & 4 & Crabs \\
Amphilocus & 4 & Small crustacean \\
Balanidae & 4 & Small crustacean \\
Serpulidae & 4 & Polychaetes \\
Nereidae & 4 & Polychaetes \\
Ostreidae & 4 & Mollusks
\end{tabular}




$\begin{array}{lll}\text { Tanaidae } & 3 & \text { Small crustacean } \\ \text { Sphaeromatidae } & 3 & \text { Small crustacean } \\ \text { Photidae } & 3 & \text { Small crustacean } \\ \text { Munnidae } & 3 & \text { Small crustacean } \\ \text { Veliidae } & 2 & \text { Insects } \\ \text { Cirolanidae } & 2 & \text { Small crustacean } \\ \text { Aoridae } & 2 & \text { Small crustacean } \\ \text { Baetidae } & 2 & \text { Insects } \\ \text { Chironomidae } & 1 & \text { Insects } \\ \text { Naididae } & 1 & \text { Insects } \\ \text { Hydrophilidae } & 1 & \text { Mollusks } \\ \text { Melitidae } & 1 & \text { Insects } \\ \text { Dysticidae } & 1 & \text { Insects } \\ \text { Noteridae } & 1 & \text { Insects } \\ \text { Caenidae } & 1 & \text { Insects } \\ \text { Libellulidae } & 1 & \text { Insects } \\ \text { Naucauridae } & 1 & \text { Insects } \\ \text { Pleidae } & 1 & \text { Insects }\end{array}$

Table 6: Biotic index of the sampling stations during the four seasons.

\begin{tabular}{|c|c|c|c|c|}
\hline \multirow{2}{*}{ Station } & \multicolumn{4}{|c|}{ Biotic index } \\
\hline & $1^{\text {st flooding }}$ & $1^{\text {st }}$ low water & $2^{\text {nd }}$ flooding & $2^{\text {nd }}$ low water \\
\hline AA1 & 4,17 & & 3,00 & 4,50 \\
\hline AA2 & 3,60 & 4,00 & 3,50 & 3,89 \\
\hline AA3 & 3,86 & & & 4,00 \\
\hline AA4 & 4,67 & 3,50 & & 3,67 \\
\hline AA5 & 4,00 & & 4,50 & 4,33 \\
\hline AN1 & 2,33 & 4,60 & 3,00 & 4,00 \\
\hline AN2 & 2,86 & 4,00 & & 4,25 \\
\hline AN3 & 3,8 & & & 4,20 \\
\hline AN4 & 4,67 & & 4,00 & 4,33 \\
\hline AN5 & 4,67 & 4,10 & & 4,50 \\
\hline AV1 & 2,25 & 3,42 & & 4,00 \\
\hline AV2 & 3,29 & & 3,00 & 3,63 \\
\hline AV3 & 2,36 & 3,56 & 2,20 & 3,13 \\
\hline AV4 & 2,25 & 4,38 & & \\
\hline CA1 & 3,40 & & & 4,50 \\
\hline $\mathrm{CA} 2$ & 4,40 & & 4,50 & 4,25 \\
\hline CA3 & 4,00 & & 4,00 & 3,67 \\
\hline CA4 & 2,71 & & 3,00 & \\
\hline CEA1 & 4,17 & & 4,00 & \\
\hline CEA2 & 3,67 & 4,00 & 3,83 & 3,88 \\
\hline CEA3 & 4,25 & 3,89 & & \\
\hline CEN1 & 4,00 & & 4,25 & 4,20 \\
\hline CEN2 & 3,82 & 3,67 & 4,33 & \\
\hline & & 2910 & & \\
\hline
\end{tabular}




\begin{tabular}{|c|c|c|c|c|}
\hline CEN3 & 4,00 & 4,00 & & \\
\hline CN1 & 4,67 & & & 4,20 \\
\hline $\mathrm{CN} 2$ & 4,75 & 4,00 & & 3,38 \\
\hline $\mathrm{CN} 3$ & 4,50 & 3,00 & 4,13 & 3,50 \\
\hline $\mathrm{CN} 4$ & 3,63 & 4,00 & & 4,40 \\
\hline CN5 & 4,6 & 4,50 & & 4,29 \\
\hline CV1 & 2,88 & 2,83 & 3,33 & 3,83 \\
\hline CV2 & & 3,83 & 3,00 & \\
\hline CV3 & 3,33 & 3,10 & 3,50 & 2,50 \\
\hline CV4 & & 3,30 & & 3,75 \\
\hline EA1 & & 3,36 & 2,20 & \\
\hline EA2 & 2,20 & 3,70 & 2,50 & 4,00 \\
\hline EA3 & & 4,43 & & 3,91 \\
\hline EA4 & 3,78 & 4,00 & 4,00 & \\
\hline EA5 & & 3,50 & 4,60 & \\
\hline EN1 & 3,60 & 3,17 & & 3,60 \\
\hline EN2 & 3,80 & & 4,50 & 3,00 \\
\hline EN3 & 3,71 & 3,33 & & \\
\hline EN4 & 3,00 & 4,40 & & 3,00 \\
\hline EN5 & & & 4,40 & \\
\hline EV1 & 1,50 & 2,83 & & \\
\hline EV2 & 1,64 & 3,00 & & 2,38 \\
\hline EV3 & 1,31 & 2,77 & 2,00 & 2,90 \\
\hline EV4 & 2,71 & 3,23 & 1,00 & 3,00 \\
\hline EV5 & & 2,92 & 1,00 & \\
\hline GA1 & 2,75 & 3,30 & 3,67 & 2,00 \\
\hline GA2 & & 2,5 & 3,75 & 3,78 \\
\hline GA3 & 1 & 3,75 & & 2,83 \\
\hline GA4 & 3,4 & 3,75 & & 2 \\
\hline GA5 & 3,5 & 4,14 & 4,11 & 3,89 \\
\hline GN1 & & 4 & & \\
\hline GN2 & 2,33 & 4 & 4,00 & 4 \\
\hline GN3 & 1 & 3 & 1,00 & 3,33 \\
\hline GN4 & 2,25 & 4,33 & 4,00 & 2 \\
\hline GN5 & 4 & 4 & 3,90 & 3,91 \\
\hline GV1 & 1 & 1,5 & 2,50 & 3,8 \\
\hline GV2 & 2,06 & 3 & 2,71 & 4,5 \\
\hline GV3 & 1,44 & 1 & 1,33 & 1,33 \\
\hline GV4 & 1,47 & & & \\
\hline VA1 & 1 & 3,2 & 1,66 & 3 \\
\hline VA2 & & 3,2 & & \\
\hline VA3 & 3 & 4,2 & & \\
\hline VA4 & 3,3 & & 3,14 & 3,78 \\
\hline VA5 & 3,3 & & & 3,86 \\
\hline VN1 & 1 & 3 & 1,00 & \\
\hline VN2 & 1 & 2,5 & 2,00 & 4 \\
\hline VN3 & 2,4 & 3,72 & 4,00 & 3,63 \\
\hline VN4 & 2,92 & 4 & & 4,17 \\
\hline
\end{tabular}




\begin{tabular}{lcccc} 
VN5 & 3,25 & 4,75 & 1,00 & 4,38 \\
VV1 & & 2 & 2,2 \\
VV2 & & 2,83 & 2,40 & 2 \\
VV3 & & 2 & 3,00 & 3,5 \\
VV4 & 3 & 4,5 & 4,50 & 4,38 \\
ZA1 & 3 & & 4,50 & 3,71 \\
ZA2 & & 3,83 & 4,50 & \\
ZA3 & 4 & 4,5 & 4,00 & 4 \\
ZA4 & 4,67 & 3,8 & 4,00 & 3,38 \\
ZA5 & & 4,5 & 4,38 & 4,14 \\
ZN1 & 4,4 & & & 3,38 \\
ZN2 & 2,5 & 3,8 & 3,50 & \\
ZN3 & 4 & 3,5 & 3,00 & 3,5 \\
ZN4 & 4,67 & 3,33 & 2,67 & 3,56 \\
ZN5 & 2,5 & 2,85 & & 3,61 \\
ZV1 & 3 & 3,53 & & \\
ZV2 & 2,71 & & & \\
ZV3 & 3,12 & & & \\
ZV4 & & & & \\
ZV5 & & & & \\
Mean & & & & \\
\hline
\end{tabular}

\section{DISCUSSION}

Most of the indexical methods are utilized in order to characterize impacts of organic pollution on the quality of water and habitats in rivers. In lakes, the control of pollution is often focused on the measures of physicochemical parameters of water and sediments or of sentinels' organisms (in USA, O'Connor, 1992; in Great-Britain, Franklin and Jones, 1994; in France, RNO, 1998).

Nevertheless, the macroinvertebrates are recognized as a good biological instrument showing the different perturbations that affect the costal ecosystems, namely, the estuaries (Le Bris and Glémarec, 1996). It is particularly a good indicator of ecological conditions at water sediment interface level, where the effects of an organic enrichment or of a more important environmental perturbation, frequently accumulate (Carmargo et al., 2004). Some indices have been suggested for the follow-up of the quality of lagoons in Europe and North America (Hily, 1984; Majeed, 1987; Grall and Glémarec, 1997; Weisberg et al., 1997; Dauer, 2000; BORJA et al., 2000). Those indices are based on the theory of $\mathrm{r}, \mathrm{K}$, and $\mathrm{T}$ strategies (Mcarthur and Wilson, 1967) and of progressive change of communities under the stress effect (Rosenberb and Resh, 1993).

No study related to this subject has been done for Benin lagoons. The index that we suggest in this study must be improved by pursuing the study in the Lake Nokoué and investigating other lagoons in Benin.

The biological index suggested here is based on the method of average scores. This method does not depend on the number of taxa but on the score attributed to these latter. This method has been suggested and applied by Armitage et al. (1983) in order to evaluate the quality of water in Great Britain.

In order to obtain the scores thus necessary, three types of approaches have been utilized in the literature: scores are attributed to aquatic invertebrates based on the observations and on the acquired knowledge on the distribution of their ecology. A score of 0 to 10 (in most of the cases) is assigned to taxon indicators. Following these indices, a score of 0 is assigned to the most polluosensitive taxa and a score of 10 to the most 
polluo-tolerant taxa (Hilsenhoff, 1988), or inversely (Alba-Tercedor and Sanchez Ortega, 1988);

1 The method of groups of stations : scores are obtained from subjectively classified sites according to gradient of pollution (example : $1=$ excellent quality; $2=\operatorname{good} ; 3=$ acceptable ; $4=$ bad ; $5=$ very bad). The scores are attributed to taxa based on their relative frequencies in the community of invertebrates at the different sites and with the use of several regressions (Lenat, 1988);

2 The scores are attributed to taxa based on maximal values taken by the major physicochemical parameters indicators of pollution where the taxa are collected (Mary, 1999).

The first approach is the one used most often in the United States (Lenat, 1993), in England (Armitage et al., 1983), in France (AFNOR, 1992), and in Colombia (Zùniga de Cardoso et al., 1994; Roldan, 1999). The second has been proposed by Lenat (1993) in order to assign more precise scores to taxon indicators used for the index NCBI (North Carolina Biotic Index). The third approach has been used by Mary (1999) in order to calculate the scores utilized for the index IBNC (Biotic Index of New Caledonia) which we adopted for this study.

Lake Nokoué (Figure 1) is the most important brackish water (about $150 \mathrm{~km}^{2}$ in low water period) in Bénin (Lalèyè et al., 2003) and the most productive in West Africa (Villanueva, 2004).

Invertebrates' diversity in the lake Nokoué can be used to elaborate biotic index. Gnohossou (2006) identified 76 taxa and 30 are observed all the time in the lake. The particularity of Lake Nokoué is the presence of acadjas which are highly enriched zones in the lake (Niyonkuru 2010). Sediments at the bottom of acadjas are colonized by polychaetes, oligochaetes and a variety of small bivalves while the branches are attacked mainly by periphyton, sessile organisms (Balanus, Ostrea and teredo worms (Teredo petiti and Bankai bagidiensis) to accelerate its eventual disintegration (Azim et al., 2005).
They are present in all other West African lagoons, but to varying degrees, high in lagoons of Lomé (Togo) and Lagos (Nigeria) and more limited in Ebrie lagoon. Indeed, in the latter, very poor in the immediate vicinity of Abidjan (Dufour et al., 1994),

Our study is, to our knowledge, the first to investigate the relationship between pollution and the benthic fauna distribution in brackish water at least in West Africa. The index elborated is simple and easy to use but enjoying simple instructions for identifying taxa the most important (thirty).

Borja et al. (2000) developed a method called AMBI (AZETI's Marine Biotic Index) inspired by Hily (1984) and by Glémarec (1986) who have divided macrobenthic organisms into 5 groups according to their sensitivity to organic pollution. This concept is also similar to the one developed for the Infaunal Index for Southern California as described by Mearns and Word (1982) and Ferraro et al. (1991).

It must be observed that this grouping has been done by Grall and Glémarec (1997) following the identification of 900 taxa. The relative proportion of every taxon in the sampling allows the calculation of the biotic index, which varies from 0 to 7 .

The difficulty of comparing these results with ours lies in that our level of identification of taxa is the family whereas it is the species in the case of Borja et al., 2000. In addition, some of our taxa are absent on the list of Borja. However, our results appear identical for certain groups such as group I (carnivorous invertebrates and big stature polychaetes) that can be, in our case, shrimps and, to a less extent, crabs and Nereidae (sea nymphs). Groups III and IV include small shellfishes such as some Mysidacae and some Balanidae, which are sensitive species. It is the same in our study.

The AMBI method equally proved efficient in the study and the diagnosis of brackish water pollution of several European and Mediterranean regions (Bazairi et al., 2005; Salas et al., 2004 ; Borja et al., 2003 ).

Benthic population of Lake Nokoué 
displays signs of disequilibrium, with the predominance of tolerant taxons, which seem to be a characteristic of natural aquatic environments with strong physicochemical variability. Species that remain most frequent in the meantime are brackish water species that tolerate more or less surcharge in organic matters. They are also species which are abundant (Grall, 1997; Borja et al., 2000). The evaluation of the water quality with the index elaborated from the species of the Lake Nokoué shows a general pollution during the flooding. Yet, we have shown that, for some stations close to the city of Cotonou (CN5 and $\mathrm{CV} 3$ for instance), the indices seem rather high during flooding seasons and low during dry season (Gnohossou, 2006). This could be explained by the evacuation of organic matters in the sea during flooding seasons and their accumulation during dry seasons. Pollution is felt primarily in coastal areas during floods and more spread (we can say "leopard skin") across the lagoon during low flow periods. It seems that the entrance of marine waters, (very less polluted) could not be "clean" on a wide range of Lake Nokoué. Without doubt, we see the influence of poor water circulation related to the presence of acadjas.

\section{COMPETING INTERESTS}

The authors declare that they have no competing interests.

\section{AUTHORS' CONTRIBUTIONS}

PG was the principal investigator of this work and drafted the manuscript. PL, PA, MG, SB and JM designed and supervised the work. The manuscript was read, revised and approved by all co-authors.

\section{ACKNOWLEDGMENTS}

The authors express their sincere gratitude to the members of Hydrobiology and Aquaculture laboratory of the Faculté des Sciences Agronomiques de l'Université d'Abomey-Calavi, Bénin for their contribution in the realization of this study. In addition, during two internships at the Laboratory of
Biological Oceanography of Arcachon (Bordeaux, France), we enjoyed the support of specialist Jean Claude SORBE who was particularly helpful in identifying the kinds of peracarid crustaceans which are most abundant in the lake. Finally, Mr. Sankaré Yacouba of University of Abobo-Adjamé, Abidjan helped us in identifying molluscs and crabs.

\section{REFERENCES}

Adounvo U, Lalèyè $\mathrm{P}$, Dauta $\mathrm{A}$, Moreau J. 2007. Facteurs écologiques et production halieutique d'une lagune Ouest africaine: le lac Nokoué au Bénin. J. Afrotrop. Zool. Special issue : 49-55.

Afli A, Glémarec M. 2000. Fluctuation à long terme des peuplements macrobentiques dans le golf du Morbihan (France), Cah. Biol.. Mar., 41 (2000): 67-89.

AFNOR 1992. Détermination de l'indice biologique global normalise (IBGN). NF T 90-350. Ass. Fr. Norm, Paris.

Aguilar Ibarra A. 2004. Les peuplements de poissons comme outil pour la gestion de la qualité environnementale du réseau hydrographique de la Garonne. Ph.D. thesis Institut National Polytechnique, Ecole Nationale Supérieure Agronomique Toulouse, France.

Alba-Tercedor JS, Sanchez Ortega. 1988. Un méteo rapido y simple para valuar la calidad bioologica de las aguas corrientes basado en el de Hellawell (1978). Limnetica, 4: 51-56.

Armitage PD, Moss D, Wright JF, Furse MT, 1983. The performance of a new biological water quality score System, Northern Pennines. Hydrobiologia, 74: 119-128. DOI: 10.1016/00431354(83)90188-4

Azim ME, Verdegem MCJ, van Dam AA, Beveridge MCM. 2005. Periphyton: Ecology, Exploitation and Management. Cabi Publishing: London.

Bazairi H, Bayed A, Hily C. 2005. Structure et bio évaluation de l'état écologique des communautés benthiques d'un écosystème lagunaire de la côte atlantique 
marocaine. C. R. Biologie, 328: 977-990. DOI: 10.1016/j.crvi.2005.09.006

Beck WM.Jr. 1955. Suggested method for reporting biotic data. Sewage et Industrial wastes 27. In Freshwater Biomonitoring et Bentic Macroinvetebrates, Rosenberg DM, Resh VH (eds). Chapman et Hall: New York; 1193-1197.

Borja A, Muxika I, Franco J. 2003. The application of a marine biotic index to different impact sources affecting softbottom benthic communities along European coasts. Mar. Pollut. Bull, 46: 835-845. DOI: $10.1016 /$ S0025326X(03)00090-0

Borja A, Franco J, Pérez VA. 2000. Marine biotic index to establish the ecological quality of soft-bottom benthos within European estuarine et coastal environments. Mar. Pollut. Bull, 40: 1100-1114. DOI: 10.1016/S0025326X(00)00061-8

Camargo JA, Alonso A, De La Puente M. 2004. Multimetric assessment of nutrient enrichment in impounded rivers based on benthic macroinvertebrates. Environ. Monit. Publish., 96: 233-249. DOI: 10.1039/b715026a

Dauer DM, Weisberg SB, Ranasinghe JA. 2000. Relationships between benthic community condition, water quality, sediment quality, nutrient loads and land use patterns in Chesapeake Bay. Estuaries, 23: 80-96. DOI: $10.2307 / 1353227$

Diday E. 1974. Recent progress in distance and similarity measures in pattern recognition. Second International Joint Conference on Pattern Recognition, pp 534-539.

Ferraro SP, Swartz RC, Cole FA, Schults DW. 1991. Temporal changes in the benthos along a pollution gradient: discriminating the effects of natural phenomena from sewage-industrial wastewater effects. Estuarine, Coast. Shelf. Sci., 33: 383407. DOI:10.1016/0272-7714(91)90064-I

Franklin A, Jones J. 1994. Monitoring and surveillance of non-radiactive contaminants in the aquatic environment et activities regulating the disposal of wastes at sea, 1992. Aquatic Environment Monitoring Report, MAFF, 40: 1-83.

Glémarec M. 1986. Ecological impact of an oil-spill: utilisation of biological indicators. IAWPRC-NERC Conference, July 1985. IAWPRC J. 18, 203-211.

Gnohossou P. 2006. La faune benthique d'une lagune ouest africaine (le Lac Nokoué au Bénin), diversité, abondance, variations temporelles et spatiales, place dans la chaîne trophique. Thèse de doctorat, Institut Nationale Polytechnique-École Nationale Supérieure Agronomique de Toulouse (INP-ENSAT), France, 175 p.

Grall J, Glemarec M., 1997. Using biotic indices to estimate macrobenthic community perturbations in the Bay of Brest. Estuar., Coast. Shelf Sci., 44: Supplement A: 43-53. DOI: 10.1016/S0272-7714(97)80006-6

Hilsenhoff WL. 1988. Rapid field assessment of organic pollution with a family level biotic index. J. North Am. Benthol. Society, 7: 65-68.

Hily C. 1984. Variabilité de la macrofaune benthique dans les milieux hypertrophiques de la Rade de Brest. Thèse de Doctorat d'Etat, Univ. Bretagne Occidentale. Vol. 1, 359 p; Vol. 2, 337 p.

Karr JR, Fausch KD, Angermeier PL, Yant PR, Schlosser IJ. 1986. Assessing biological integrity in running waters: a method and its rationale. Illinois Nat. Hist Surv Special Publication 5. 28p.

Kohonen T. 2001. Self-Organizing Maps. Springer Series in Information Sciences 30, Springer-Verlag, Berlin.

Kristensen E, Anderson FO. 1993. Determination of organic carbon in marine sediments: a comparison of two CHN analyzer methods. J. Experiment Mar. Biolo. Ecol., 109: 15-23. DOI: 10.1016/0022-0981(87)90182-1

Lalèyè P, Niyonkuru C, Moreau J, Teugels G. 2003. Spatial and seasonal distribution of the ichthyofauna of Lake Nokoué, Bénin, 
West Africa; Afr. J. Aquat. Sci., 28(2): 151-161. South Africa DOI: http://dx.doi.org/10.2989/1608591030950 3779

Le Bris H, Glémarec M. 1996. Marine et brackish ecosystems of south Brittany (Lorient and Vilaine Bays) with particular reference to the effect of the turbidity maxima, Estuar. Coast. Shelf Sci., 42: 737-753. DOI:10.1006/ecss.1996.0047

Lek S, Giraudel JL, Guégan JF. 2000. Neural networks : algorithms et architectures for ecologists et evolutionary ecologists, pp. 3-27. In Artificial neuron networks: application to ecology et evolution, Lek S, Guégan JF (eds). Op. cit.

Lek S, Delacoste M, Baran P, Dimopoulos I, Lauga J, Aulagnier S. 1996 Application of neural networks to modelling nonlinear relationships in ecology. Ecol. Model., 90: 39-52. DOI: http://dx.doi.org/ 10.1016/0304-3800(95)00142-5

Lenat DR. 1988. Water quality assessment of streams using a qualitative collection method for benthic macroinvertebrates. , J. North Am. Benthol. Soc., 7: 222-233.

Lenat DR. 1993. A biotic index for the southeastern United States: derivation and list of tolerance values, with criteria for assigning water-quality ratings, J. North Am. Benthol. Soc., 12: 279-290.

Majeed SA. 1987. Organic matter and biotic indices on the beaches of North Brittany. Mar. Pollut. Bull, 18(9): 490-495. DOI: 10.1016/0025-326X(87)90360-2

Manly BFJ. 1995. The conservation of freshwater fish: past and present experience. Biol. Conserv., 72: 259-270.

Mary N. 1999. Caractérisation physicochimique et biologique des cours d'eau de la Nouvelle Calédonie, proposition d'un indice biotique fondé sur l'étude des macro invertébrés benthiques. Thèse de Doctorat. Université Française du Pacifique Nouméa, Nouvelle Calédonie.

Math Works Inc. 1999. Matlab : The language of technical computing. var pag.

Mathuriau C. 2002. Les macroinvertébrés des cours d'eau andins du Sud-Ouest de la Colombie : Ecologie et bioindication. Thèse de doctorat. Université Toulouse III- Paul Sabatier, France, pp 305.

Mcrrthur RH, Wilson EO. 1967. The Theory of Island Biogeography. Princeton University Press, Princeton, USA.

Mearns AJ, Word JQ. 1982. Forecasting effects of sewage solids on marine benthic communities. In Ecological Stress and the New York Bight: Science and Management, Mayer GF (ed.). Estuarine Research Federation, Columbia: South Carolina; 495-512.

Michalski RS, Stepp RE, Diday E. 1981. A recent advance in data analysis Clustering objects into classes characterized by conjunctive concepts. In Progress in Pattern Recognition (Vol. 1), Kanal LN, Rosenfeld A (Eds.). NorthHollet: New York; 33-56.

Niyonkuru C, Lalèyè $\mathrm{P}$, Villanueva $\mathrm{MC}$, Moreau J. 2003. Population parameters of main fish species of Lake Nokoué in Benin. Abstract. J. Afrotrop. Zool., Special issue : 149-155.

Niyonkuru C, Laleye P, Moreau J. 2010. Impact of acadja fisheries on the population dynamics of Sarotherodon melanotheron and Hemichromis fasciatus in Lake Nokoué Bénin. West Africa. Knowl. Manag. Aquat. Ecosyst, 397: 01. DOI: $10.1051 / \mathrm{kmae} / 2010019$

Ohio Epa. 1987. Interoffice Communication Regarding ARMCO's Elimination of Blast Furnace Blowdown in Outfall 001. From Mike Zimmerman, Southwest District Office. To Bob Phelps and John Kirwin, Industrial Waste Water, Central Office. August 21, 1987.

Resh VH, Jackson JK. 1993. Rapid assessment approaches in benthic macroinvertebrate biomonitoring studies. In Freshwater Biomonitoring and Benthic Macroinvertebrates, Rosenberg DM, Resh VH (eds). Chapman and Hall: New York; 195-233.

Rioux S, Gagnon F. 2001. Développement d'un indice biotique pour évaluer l'état de 
santé des petits cours d'eau en milieu agricole dans le bas Saint - Laurent. FAPAQ, Direction de l'aménagement de la faune de la région du bas Saint Laurent. Document du Bape Bio 78. 93p.

Roldan G. 1999. Los macroinvertebrados su valor como indicatores de la calidad de agua. Revista de la academia Colombiana de Ciencias Exactas Fisicas y Naturales, 23 : 375-387.

Rosenberg DM, Resh VH. 1993. Introduction to freshwater biomonitoring and benthic macroinvertebrates. In Freshwater Biomonitoring and Benthic Macroinvertebrates, Rosenberg DM, Resh VH (eds). Chapman et Hall: New York, USA; 3-9.

Salas F, Neto JM, Borja A., Marques JC. 2004. Evaluation of the applicability of a marine biotic index to characterize the status of estuarine ecosystems: the case of Mondego estuary (Portugal). Ecol. Indicator, 4: 215-225.

Stark JD. 1993. A macroinvertebrate community index of water quality for stony streams. New Zealand J. Mar.
Freshwater Research, 27: 463-478. DOI: http://dx.doi.org/10.1080/00288330.1993. 9516588

Stoddard J, Larsen DP, Hawkins CP, Johnson RK, Norris RH. 2006. Setting expectations for the ecological condition of streams: the concept of reference condition. Ecol. Appl., 16:1267-1276.

Tachet PH, Richoux Bournaud P, UsseglioPolatera M. 2000. Invertébrés d'Eau Douce: Systématique, Biologie, Ecologie. CNRS edition; $588 \mathrm{p}$.

Ward JH. 1963. Heirarchical grouping to optimize an objective function. J. Am. Stat. Assoc., 58: 236-244. DOI: 10.1080/01621459.1963.10500845

Weisberg SB, Ranasinghe JA, Dauer DM, Schaffner LC, Diaz RJ, Frithsen JB. 1997. An estuarine benthic index of biotic integrity (B-IBI) for Chesapeake Bay. Estuaries, 20(1): 149-158. DOI: $10.2307 / 1352728$

Woodiwiss FS.1964. The biological system of stream classification used by the Trent River Board. Chemist. Indust., 11: 443447. 